\title{
COMPARATIVE ANALYSIS OF BROADBAND INTERNET DEVELOPMENT FOR DIGITAL ECONOMY IN CHINA AND INDONESIA
}

\author{
ANALISIS KOMPARASI PEMBANGUNAN INTERNET \\ BROADBAND UNTUK MENDUKUNG DIGITAL EKONOMI \\ DI CINA DAN INDONESIA
}

\author{
Riva'atul Adaniah Wahab \\ School of Public Policy and Management, Tsinghua University, Beijing 100084, China \\ riva002@kominfo.go.id
}

Naskah Diterima: 3 Mei 2019; Direvisi : 9 September 2019; Disetujui : 9 September 2019

\begin{abstract}
It is important to promote broadband internet development because of its role in supporting economic activities. The $10 \%$ increase in broadband penetration triggered economic growth of $1.38 \%$ in middle-income countries. In 2050, China is predicted to continue as the world economy leader, while Indonesia moves from position 8 to 4 . This qualitative study uses "nation as an object of study" approach of cross-national comparison in comparing broadband internet development for digital economy in China and Indonesia in order to realize their future economy position. Four compared parameters are internet infrastructure profile, digital economy overview, broadband internet development strategy, and broadband internet regulation for digital economy. Its result is expected to give direct benefit to regulator in making further plans, strategies, and regulations of broadband internet, particularly for Indonesian government. This study finds the telecommunication infrastructures to support broadband internet and digital economy regulations in China are more mature than Indonesia. Nonetheless, Indonesia is very active in the current e-commerce development. However, Indonesia needs to expand in other digital economy activities such as fintech and provide human resources with knowledge and skills as part of an important component of the digital economy. Indonesia also needs to learn from China regarding e-commerce regulations, such as taxation and product standards. This effort requires the collaboration of government, academics, and industry players to strengthen the role of broadband internet in digital economy, in China and in Indonesia.
\end{abstract}

Keywords: broadband internet, digital economy, e-commerce. 


\section{INTRODUCTION}

The presence of internet in the convergence era has encouraged the emergence of various supporting technologies, access or new providers, and new internet-based products (Curran, Fenton, \& Freedman, 2016). The ease of internet access, through fixed line and mobile, also contributes to the increase of world internet penetration year to year. In 2005, International Telecommunication Union (ITU) recorded internet user in the world at around 16\% of 6.5 billion world population while in 2017 increased to $48 \%$ of 7.4 billion.

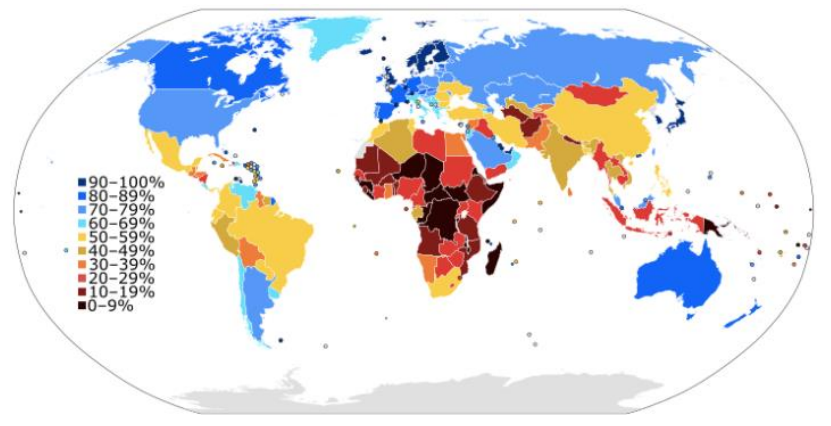

Figure 1. Worldwide Internet Users and Internet Users in 2016 as a Percentage of a Country's Population Source: International Telecommunication Union

In the past few years, high-speed internet access or broadband internet has developed along with the increasingly complex activities of internet usage, for example, financial transactions (Wahab, 2016). Recommendation I.113 ITU defines broadband as a transmission capacity which is faster than Integrated Service Digital Network (ISDN), 1.5 or 2.0 Mbps. According to the Organization for Economic Cooperation and Development (OECD), broadband speed is at least 256 kilobytes per second (Mastel, 2016). Broadband allows the provision, processing, and distribution of information to be carried out more quickly, efficiently, effectively, transparently, and accountable thus the information does not lose the value and can even create added value for the community. The international community has set various broadband planning targets, broadband services must be affordable for $40 \%$ of households at a price of less than $5 \%$ of monthly income, $50 \%$ of internet users in developing countries, accelerated broadband internet deployments in schools, and connecting villages (The Ministry of National Development Planning /BAPPENAS, 2014).

Table 1. Worldwide Broadband Subscriptions

\begin{tabular}{lccc}
\hline & 2007 & 2010 & 2016 \\
\hline World population & 6.6 & 6.9 & 7.3 \\
Fixed broadband & billion & billion & billion \\
- Developing world & $2 \%$ & $8 \%$ & $11,9 \%$ \\
- Developed world & $18 \%$ & $4 \%$ & $8,2 \%$ \\
Mobile broadband & $4 \%$ & $11 \%$ & $49,4 \%$ \\
- Developing world & $1 \%$ & $4 \%$ & $40,9 \%$ \\
- Developed world & $19 \%$ & $43 \%$ & $90,3 \%$ \\
\hline
\end{tabular}

Source: International Telecommunication Union

Internet infrastructure has an important role in national development. It is an enabling tool for economic growth and increased productivity (Hirawan, 2018). Its development is important to implement because it can support economic activities. The concept of internet economy come up as a result of the dependency of economy activity and society to the internet (Gnezdova, Chernyavskaya, \& Rubtsova, 2016). Internet access enables poverty alleviation through its usage in economic activities and the provision of online education (CNNIC, 2018). Increased penetration of mobile internet and internet users have an impact on increasing the use of online platforms or social media as instruments in online businesses, enabling relationships and communication between suppliers and customers, as well as other parts in business chains (Hirawan, 2018). Based on The Digital Economy and Society Index (DESI) European Commission, the distribution of broadband and its quality is one of the connectivity dimension in measuring the 
development of digital economy in European Union countries (Ministry of Communications and Informatics, 2016).

The 2010 World Bank study found that in low-income and middle-income countries, a $10 \%$ increase in broadband penetration triggered $1.38 \%$ of economic growth. This increase was higher than in high-income countries which only contributed $1.12 \%$. Booz and Company (2009) predicted that a $10 \%$ increase in broadband access in a year correlated with a $1.5 \%$ increase in labor productivity in 5 years ( The Ministry of National Development Planning /BAPPENAS, 2014). McKinsey and Company estimated a $10 \%$ increase in penetration of household broadband internet would drive the growth of $0.1 \%-1.4 \%$ of Gross Domestic Product (GDP). Oxford Economics (2016) claimed that increasing mobile internet penetration would contribute to an increase US\$ 58.1 billion GDP and open one million new job opportunities in 2020 at South East Asia. At the regional and village level, The Centre for Strategic and International Studies (CSIS) study (2018) argued that a 10\% increase in network coverage contributed to the Gross Domestic Regional Product (GDRP) increase of $0.92 \%$. The internet opens the opportunity to create "online work" that allows users to make money through internet-based work. For example, villages in Indonesia are involved in online business by creating capacity building programs to improve customer service skills (Hirawan, 2018).

Based on the World Internet Conference (WIC) report, the digital economy is predicted to contribute US\$ 2 trillion in world GDP in 2020. In 2017, 171 million people work in the digital economy-related sector, $22 \%$ of overall employment in the world (Shenggao, 2018). In 2050, China is predicted to continue to lead the world economy whereas Indonesia moves from position 8 to position 4. When Indonesia makes it into the top five it will be interesting for a further study.

\begin{tabular}{ccccc|}
\hline & $\mathbf{2 0 1 6}$ & $\mathbf{2 0 5 0}$ & \\
\hline China & $\mathbf{1}$ & $\mathbf{1}$ & China \\
\hline US & $\mathbf{2}$ & $\mathbf{2}$ & India \\
\hline India & $\mathbf{3}$ & $\mathbf{3}$ & US \\
\hline Japan & $\mathbf{4}$ & $\mathbf{4}$ & Indonesia \\
\hline Germany & $\mathbf{5}$ & $\mathbf{5}$ & Brazil \\
\hline Russia & $\mathbf{6}$ & $\mathbf{6}$ & Russia \\
\hline Brazil & $\mathbf{7}$ & $\mathbf{7}$ & Mexico \\
\hline Indonesia & $\mathbf{8}$ & $\mathbf{8}$ & Japan \\
\hline UK & $\mathbf{9}$ & $\mathbf{9}$ & Germany \\
\hline France & $\mathbf{1 0}$ & $\mathbf{1 0}$ & UK \\
\hline$\square$ E7 economies & $\square$ & G7 economies \\
\hline Sources: IMFfor 2016 estimates, PwC analysisfor projections to 2o5o \\
\hline
\end{tabular}

Figure 2. Emerging Markets will Dominate The World's Top 10 Economics in 2050 (GDP at PPPs)

Several studies related to the issue of development of broadband internet and economy have been carried out, among others: Salahuddin (2015) assessed the linkage between the internet users and economic growth in South Africa. Using Autoregressive Distributed Lag (ARDL), result showed the positive and significant relationship between both variables (Salahuddin \& Gow, 2015). Similar to Salahuddin (2015), bringing the broadband focus, Pradhan (2015) wrote about the short-run and long-run relationship between ICT infrastructure and economic growth in Asian, starting from 2001-2012. Fixed broadband was one of the variable of ICT index in this case (Pradhan, Arvin, \& Norman, 2015). Jorgenson and Vu (2016) through the title "The ICT revolution, world economic growth, and policy issues" described the important policy issues about ICT revolutions in promoting the economic growth. Program strategy was one of the important issues in implementing the ICT policy. 
Network infrastructure was needed to increase the connected economy (Jorgenson \& Vu, 2016).

Relating to the concept of internet economy, Gnezdova (2016) mentioned that internet had created the new business model contributing to the economy development. Online resources also provided the efficiency in the economy activities (Gnezdova et al., 2016).

Using the cross-country methodology, Mitrovic (2015) compared the broadband adoption level of Western Balkan countries to the European Union countries, also described the digital gap. The result provided strong and weak indicator of broadband that should be attached as priority in political intervention. Building the information society and improving the economic competitiveness were part of the result (Mitrovic, 2015).

Another comparative study was also conducted by Gunaratne in 2015. Malaysia, India, Indonesia, and Australia were researched to describe their rationale, scope, funding, technology, and current status of national broadband network. The result was found that awareness initiative is important to increase the broadband penetration. Broadband should be affordable and acceptable by the user (Gunaratne, P, Fernando, \& Rohman, 2015).

The latest research, Curran (2018) wrote about three factors that impact to the growth of broadband in Korea, those were policy principles, regulatory decisions, and population density (Curran et al., 2016).

This research focuses on comparing the broadband internet deployment between two countries predicted to occupy the high position in digital economy in the future, learning the policy initiative of others. In 2050, China is predicted to continue to lead the world economy whereas
Indonesia moves from position 8 to position 4 . Indonesia makes it into the top five. It is interesting to be made further study. According to the importance of broadband internet, this research analyzes the current state, the strategies, and the regulations of the broadband internet development implemented in China and Indonesia. To achieve the target entering the top 5 economics in 2050, Indonesia can learn China's broadband internet deployment for digital economy. The result is expected to give direct benefit to regulator in making further plans, strategies, and regulations of broadband internet development, particularly for the Indonesian government.

\section{METHODOLOGY}

This qualitative research uses cross-national comparison. Because these two countries have similarity in the growth of digital economy, the "nation as an object of study" approach of crossnational comparison is conducted. Using this method, researcher can gain deeper understanding by comparing particular issues of broadband internet development in China and Indonesia. Thus, researcher can learn the policy initiative of others, the similarities and differences among countries which are studied (Gharawi, Pardo, \& Guerrero, 2009).

The data are obtained through literature studies, for instance, journals, books, news, previous researches, and other sources. Collected data are consisted of information about existing condition in China and Indonesia related to 4 main parameters:

\section{Internet infrastructure profile}

This part presents empirical evidences of the existing broadband internet infrasctructure in both countries. The indicators include internet user, 
fixed broadband penetration, mobile cellular penetration, fixed telephone penetration, followed by the definition of each indicator. Graphics are provided to give easier experience in understanding the comparison between China and Indonesia.

2. Digital economy overview

This part gives information about the digital economy development in China and Indonesia, including the usage of internet in digital economy, the local and global e-commerce transaction, the contribution of digital economy activities to national and global economy, and other impacts of internet use in economy activities.

3. Broadband internet development strategies

This part explains the existing, planned, and target strategy of broadband internet development.

4. Broadband internet regulations for digital economy in both countries.

This part informs the policies or regulation to implement strategy and achieve the targets.

In the end of result and discussion section, the important points of each parameter are delivered in comparison table. Data analysis is provided after presenting the collected data into the table. Its purposes are to get clear picture of existing parameter condition and easier observation. In this process, the researcher also gives more analysis about the differences and similarities between both countries. The study is closed by conclusion and recommendation, what should be studied from the better country. If China has better condition, what Indonesia should learn from China, and vice versa.

\section{RESULTS AND DISCUSSION}

\section{Internet Infrastructure Profile in China and} Indonesia

Using the weighted average method, the ITU World Telecommunication/ICT Development Report and Database presents the profiles of each country as follows:

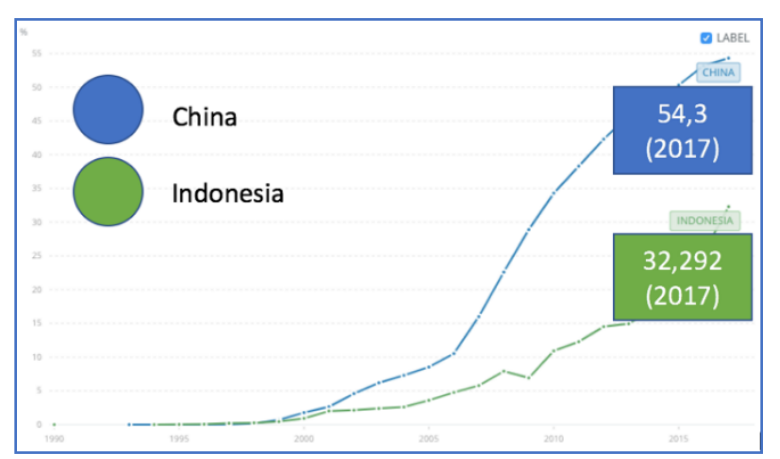

(a)

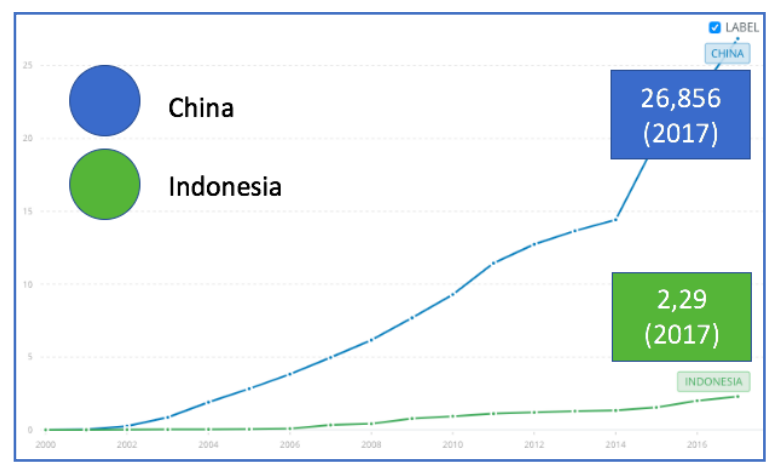

(b)

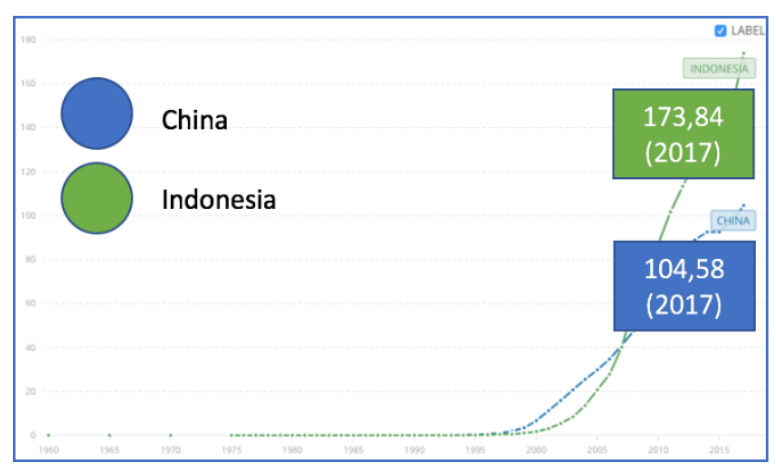

(c) 


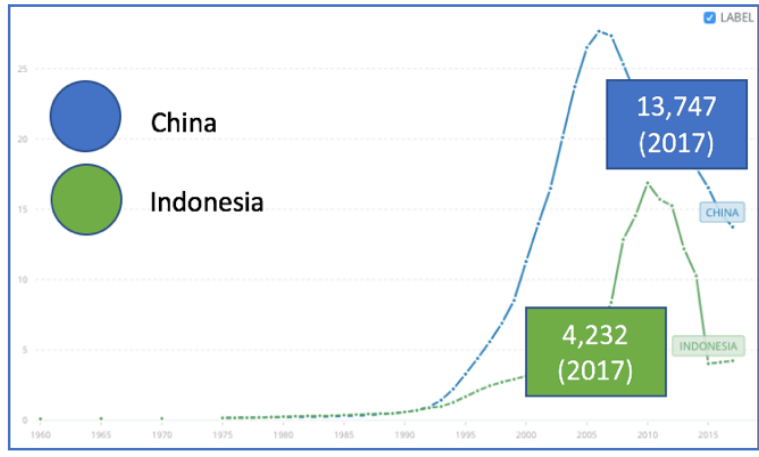

(d)

Figure 3. (a) Internet User (\% of Population), (b) Fixed Broadband Subscription (per 100 people), (c) Mobile Cellular Subscription (per 100 people), (d) Fixed Telephone Subscription (per 100 people)

ITU defines the terms used as follows: Internet user is defined as individual accessing the internet using computer, mobile phone, personal digital assistant, games machine, digital TV, and other devices in the last 3 months.

Fixed broadband subscriber is the number of customer connected to the public internet with highspeed access (Transmission Control Protocol (TCP)/Internet Protocol (IP) connection), with downstream speed equals to or more than $256 \mathrm{kbit} / \mathrm{s}$ that can be accessed using cable modem, Digital Subscriber Line (DSL), fiber-to-the-home/building, satellite broadcast, and terrestrial fixed wireless broadband. Including subscription by organization or household.

Mobile cellular subscriber is defined as customer connected to public telephone services through Public Switch Telephone Network (PSTN) using cellular technology. Customer is calculated based on postpaid and prepaid number that was active in the last 3 months. The connection is built via Hypertext Transfer Protocol (HTTP) and Internet Protocol in the previous three months. Data do not include customer accessing telephone services via data card or Universal Serial Bus (USB) modem, private trunked mobile radio, telepoint, radio paging, and telemetry services.

Fixed telephone subscriber is active number for fixed telephone line, Voice Over IP (VoIP), fixed Wireless Local Loop (WLL), Integrated Services Digital Network (ISDN) voice channels, and fixed public payphones.

According to the Akamal Technology report for Q1 2017, China recorded an average connection speed of 7.6 Mbps while Indonesia was not much different, reaching 7.2 Mbps. In worldwide broadband speed league 2018 compiled by cable.co.uk and M-Lab, Indonesia is ranked 83th out of 90 countries with an average speed of $5.77 \mathrm{Mbps}$, while China is not included in this 90 list.

The result of the survey of access and use of information and communication technology (ICT) by individual in 2016 recorded internet ownership by household in Indonesia only reaching 36\% (Wahab, 2016).

\section{Digital Economy Overview in China}

The growth of China's digital economy in the past 10 years has continued to increase to reach US\$ 3.8 trillion in 2017 , contributing to $1 / 3$ China's GDP. According to the Boston Consulting Group report, China's digital economy is projected to increase at US\$ 16 trillion by 2035 with a penetration rate across the economy of $48 \%$ (Shenggao, 2018). One proof of the digital economy developments in China is the growth of e-commerce. In 2017, the National Bureau of Statistics of China noted that China's e-commerce contributed around $23.8 \%$ of total retail sales in China and $40 \%$ of total global retail sales. This number is predicted to rise to $33.6 \%$ in 2019 (Fujino, 2018). The total retail sales of China's consumer goods reached RMB 36,626.2 Billion, increasing at 
around $10.2 \%$ from the previous year. The recorded consumer goods online retail sales reached RMB $7,175.1$ billion, an increase of $32.2 \%$ from the previous year. For physical products, online retailing reached RMB 5,480.6 billion, $15 \%$ of total retail sales of consumer goods, increased by $28 \%$ from the previous year. Likewise, food, clothing, and daily goods increased by $28.6 \%, 20.3 \%$, and $30.8 \%$ respectively. Online retail sales of non-physical products reached RMB 1,694.5 billion, an increase of $48.1 \%$. Sales of non-physical goods such as services are faster than physical goods (CNNIC, 2018). China's cross-border e-commerce trade posted a turnover of RMB 90.24 billion, rising for $80.6 \%$ compared to 2016 (Xinhua, 2018).

Another form of broadband internet uses for digital economy is the development of sharing economy that contributes to economic growth, innovation, and expansion of employment. Business sharing of bicycle had reached 221 million customers at the end of 2017, an increase of $108 \%$ from the previous year. This business expansion covers all major cities in China. In addition, the food, travel, and engagement businesses are also growing with the availability of online ordering applications. Online food orders increased by $64.6 \%$ to 343 million orders, travel orders increased by $25.6 \%$ to 376 million, and live reality shows increased 75.22 million to 220 million. Online payments complement the economy's digital activity in China. The scale of the cashless payment user reached 531 million. As many as 571 million of them use mobile online payments, an increase of $12.3 \%$ compared to that of 2016. The use of online payments is also used by rural communities. It was noted that there was an increase in the use of online payment in the rural area by $47.1 \%$ compared to the end of 2016 . The purchase of financial internet products reached 129 million, an increase of $30.2 \%$. The internet financial utilization ratio reached $16.7 \%$, an increase of $3.2 \%$ from that of 2016. In the government sector, Alipay and Wechat which are connected to broadband internet networks are used to pay for government services such as social security, taxation, transportation, education, healthcare, and payment utilities. Online government users reached 485 million. The utilization ratio reached $44 \%$, increasing at around $26.8 \%$ compared to that of 2016 (CNNIC, 2018).

\section{Broadband Internet Development Strategy in China}

In 2014, international internet bandwidth per user reached 5 kilobits per second. China's bandwidth gateway had reached 7.320,180 Mbps at the end of 2017 . This capacity increased by $10.2 \%$ from the previous year. The total length of the optical cable line reached 36.06 million kilometers. The base station for mobile communication built to support mobile broadband internet had reached 6,041 million. In general, this mobile broadband internet infrastructure is capable to cover city and district areas (CNNIC, 2018).

The 13th Five Year Plan China targeted 90\% of poor villages to reach broadband internet. Therefore in 2018, China focused on broadband development in rural areas with the aim of reducing digital divide between rural and urban areas (CBNEditor, 2018). The development plan was published in the "Implementation Plan Concerning the Advancement of Internet Poor Support (20182020)" made by the Ministry of Industry and Information Technology. In this agenda, China targeted more than $90 \%$ of poor villages with affordable broadband infrastructure in 2020. As 
many as $98 \%$ of the total 122,900 poor villages across China will be abble to afford broadband networks. To realize this target, China has started three pilot projects for telecommunications services with an investment value of 40 billion yuan (US\$ 6 billion). This project will be able to connect 130,000 administrative villages (including 43,000 poor villages) with fiber optics. The infrastructure will provide experience of internet speeds reaching 65 Mbps, faster than the average internet speed in urban areas. In addition to the target in the rural area, in 2020 China also targets fixed broadband deployment covering $70 \%$ of households, increasing 3G/Long Term Evolution (LTE) customers to $85 \%$ of the population, broadband availability for $98 \%$ village administrations, broadband speed access for urban and rural households, respectively 50 Mbps and 12 Mbps, it can even reach 1 Gbps for developed cities. The government efforts to achieve these targets include (chinadaily.com.cn, 2018):

1. Integrating $4 \mathrm{G}$ networks by targeting $4 \mathrm{G}$ coverage to poor villages into the pilot project. The government provides subsidies of $30 \%$ of the total projects with different proportions for each region, for example, $15 \%$ for the eastern region.

2. Enforcing operators to provide high-speed networks at low-cost and implement specific policies for the low-level economy. Thus, they are more affordable by their purchasing power.

3. Accelerating the realization of intelligent terminals and application services, and increasing the promotion of platforms for educational, health, and economic needs, including agricultural production for rural communities.
4. Investing funds of up to US\$204 billion and inviting the private sector to contribute.

5. A pilot project with targeted broadband utilization for poor schools and special education institutions.

6. Through the 2016-2020 Communication Industry Development Plan, China conducts research for deploying a $5 \mathrm{G}$ commercial network that promises a higher speed broadband internet experience and enables the integration and innovation of mobile internet development, industrial internet, and the Internet of Things (CNNIC, 2018).

7. Through the "Broadband China" program, China increased the bandwidth capacity of international gateways and expanded the reach of Base Tranceiver Station (BTS) for mobile internet (CNNIC, 2018).

\section{Broadband Internet Regulation for Digital Economy in China}

To support the achievement of targets and implementation of strategies, special policies are needed to improve organizational leadership, the system environment, regulation for construction, improve fiscal support, optimize spectrum planning, strengthen personnel training, and develop international cooperation. The challenge is the need to establish regional coordination of broadband networks, increase the level of broadband network applications, and enhance broadband network security capabilities (A4AI, 2018). To strengthen the internet role in national development, China has formulated a variety of policies to ensure that the internet can be utilized by the public, especially to support the growth of the digital economy. These regulations include (CNNIC, 2018): 
1. New Law of Cyber Security

China published the Cyber Security Act on June 1, 2017. This regulation is a new basis for regulating network information dissemination and cybercrime law. After evaluating the implementation of regulations in December, it was decided to accelerate the legislative process of personal information protection regulations, critical infrastructure protection, hierarchical cybersecurity protection, and cross-border data evaluation. The aim is information security will increase along with compliance and law enforcement.

\section{New Law of E-Commerce}

The Standing Committee of the National People's Congress (NPC) approved new regulations for e-commerce. This rule came into effect since January 1, 2019. This regulation extends legal protection for consumers and brand owners and breaks down China's reputation as a source of counterfeit goods. In addition, this law also promotes cross-border e-commerce and participation of small and micro businesses (Xinhua, 2018). Close supervision and market regulation are needed because of the rapid growth of China's e-commerce market. Beginning with the enactment of this regulation, China has published e-commerce policies and standards consisting of the Action Plan for Promoting the Development of E-Commerce in Three Years (2016-20180) and The Guide for Work on Standardization of Online Retail. In July 2017, an internet court was formed in Huangzhou to resolve online shopping contract disputes in the jurisdiction, other internet cases, and litigation fees related to online transactions. At the end of 2017, there were 3,064 of 4,859 cases closed. Issues were regulated including the types of e-commerce operators recognized in the law consisting of 1) Platform
Operators, for example, shopping sites Taobao and Alibaba. 2) Operators on Platforms, for example, operating an online store vendors on Taobao, and 3) Online Sellers such as e-commerce use social media applications (Fujino, 2018). In addition, the new regulation also regulates taxation and business registration, personal data protection, and intellectual property protection (Zhang, 2018).

\section{Financial Technology (Fintech) Regulation}

The Chinese government's policy to improve financial inclusion through digital finance has driven greater innovation. Today, China is the largest peerto-peer $(\mathrm{P} 2 \mathrm{P})$ lending market share and has several Unicorns that are focused on payments and remittances. A total of 2,136 P2P lending platforms were recorded completing transactions of RMB 82.5 billion per month in July 2015 (Arner \& Barberis, 2015). Before 2015, China's banking regulator imposed rules on internet payment and third-party payment services. After that, Guideline on Promotion of Health Development of Internet Finance was published as the first comprehensive regulation on fintech. This guideline sets out the basic rules of internet payment, online insurance, online lending, crowdfunding, and online sales of funds. In December 2015, the China Banking Regulatory Commission (CBRC) issued a draft of P2P lending regulation and the People's Bank of China (PBOC) issued regulations on online payment non-banking service providers (Zhou, Arner, \& Buckley, 2015).

\section{Digital Economy Overview in Indonesia}

According to Garther's research, an increase in online activity is triggered by the high use of mobile devices, for instances, smartphones and tablets. Economic digital activity contributes as 
much as double digits to Indonesia's GDP in the last 2 years (Molasiarani, 2017). The Center for Indonesian Policy Studies (CIPS) research noted that Indonesia's digital market contribution reached 10\% in 2018. In 2017, the Central Bureau of Statistics recorded a digital market contribution to Indonesia's GDP at $4 \%$, arising from $3.61 \%$ at the previous year (Kompas.com, 2018). Google Temasek Report 2016 predicted Indonesia's online economy will reach US\$ 197 billion or $40 \%$ of the total economy in the Southeast Asia region in 2025 (Hirawan, 2018). The value of e-commerce transactions in Indonesia in 2015 reached US\$ 3.56 billion. The value of ecommerce retail business in 2018 reached US\$ 10.92 billion, increasing from 2017 which only recorded US\$ 8,21 billion (Kemenkominfo, 2016b). The growth of Indonesia's e-commerce transactions is predicted to reach US\$ 16 billion in 2022 (Wanda, 2018a). The Indonesian Capital Defense Coordination Agency states that investment in Indonesia's digital economy has reached US\$ 4,8 billion in 2017. The McKinsey Global Institute says Indonesia has around 30 million online shoppers in 2017 (Wanda, 2018b). The Indonesia digital economy era is also marked by the growing number of start-ups (Kemenkominfo, 2016b). In line with the digital economy vision in 2020 , the government is targeting to establish 1.000 start-ups with a business valuation of US\$ 10 billion and 50 e-commerce per year with a transaction value of US\$ 130 billion.

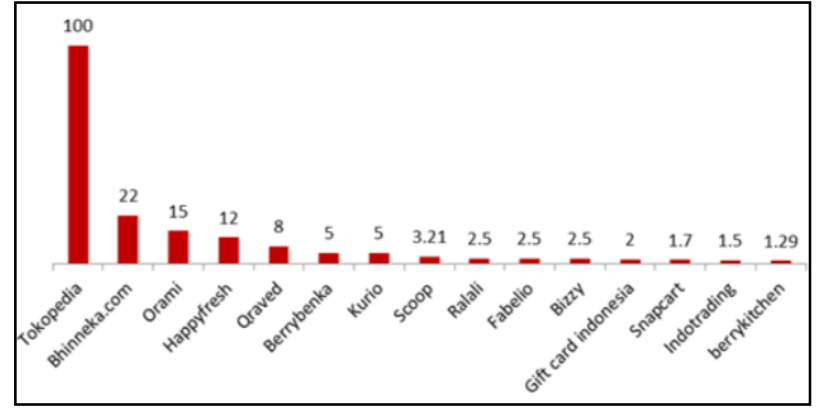

Figure 4. Fifteen Startup Funding in Indonesia (US\$ Million)

Source: Tech in Asia, 2016

The development of digital economy in Indonesia was also marked by the presence of online transportation applications; Gojek, Uber, and Grab which changed the business model of mass transportation. Based on the research of the Demographic Institute, Faculty of Economics and Business, University of Indonesia (LD FEB UI), GoJek contributed Rp8.2 trillion per year to the national economy with around one million partners. The total value of Go-Food application transactions in a year can reach Rp1.7 trillion. If accumulated, the value of Go-Jek transaction in a year is Rp9.9 trillion (Sumartomdjon, 2018).

In addition, the application of billing purchases and payments is increasing, making it easier for Indonesian people to conduct financial transactions, for examples, to order real-time taxis, order products/goods, buy tickets, or buy electricity vouchers and pulses. In Indonesia, there have been many startups that have built a foundation in fintech technology such as Go-Pay, Amartha, and others, but its use for daily transactions is not massive (Wanda, 2018a). 


\section{Broadband Internet Development Strategy in Indonesia}

In 2016, Indonesia international internet bandwidth per user reached 6.23 kilobits per second. Until the third quarter of 2016, the number of BTS of four giant operators in Indonesia reached only 163 thousand. Indonesia is already deploying fiber optic network more than 154 thousand in length through internet provider project, for instances Telkom (IndoTelko, 2019), XL (Tari, 2019), and government project, for instance, Palapa Ring (Katadata.co.id, 2019).

The Indonesian government's commitment to roll out broadband services is embodied in Presidential Regulation No. 96/2014 concerning Indonesia Broadband Plan. The concept is outlined in the National Broadband Policy Plan (Ministry of Communications and Informatics, 2012). Indonesia plans to deploy fixed broadband in urban areas to reach $71 \%$ of households with $20 \mathrm{Mbps}$ speeds and $30 \%$ of population, including mobile access that can be reached by all population at a speed of $1 \mathrm{Mbps}$ in 2019. Whereas fixed broadband targets in rural areas in the same years cover $49 \%$ of households with 10 Mbps speeds, $6 \%$ of population, and $52 \%$ of mobile accesses at a speed of 1 Mbps. To increase the adoption of broadband services, maximum service prices are targeted at $5 \%$ of the average monthly income at the end of 2019. Efforts made by the government to achieve these targets include ( The

Ministry of National Development Planning /BAPPENAS, 2014):

1. Making broadband internet as part of universal access and incorporating broadband in Universal Service Obligation (USO).

2. Infrastructure deployments include the infrastructure provision through regulatory intervention programs and also stimulant and catalyst funding, consisting of:

a. Economic connectivity including the Palapa Ring Project, Satria Satellite, Joint Pipe Project, and Wireless Connectivity Pilot Project for Rural Broadband. Palapa Ring aims to provide the backbone of the national telecommunications system in the form of fiber-optic networks that connect districts and cities in Indonesia, especially for noncommercial areas. Palapa Ring development is carried out with a government and business partnership (Public Private Partnership/PPP) cooperation scheme (Clinten, 2018).

b. Enabling consists of USO Fund Reform and the development of National Human and Industrial Resources.

3. Encouraging broadband internet-based services and applications through stimulation of application and service development, maintaining service quality, price, and security, and increasing consumer protection. The government encourages interconnection costs to a minimum thus, people can enjoy low-cost services.

4. Encouraging the use of broadband internet in various sectors, especially in priority sectors including e-government, e-health, e-education, e-logistics, and e-procurement, and anticipate the impact of broadband.

5. Capacity building programs to improve digital literacy, computer administration, and broadband education and training.

6. Investing to the broadband deployment at $10 \%$ of the total needed fund. The estimation of the 
needed funds are around Rp278 trillion or $0.46 \%$ of GDP.

Challenges faced are 1) broadband Indonesia still lagging at the global level, 2) backbone coverage is not evenly distributed, especially in eastern Indonesia, and 3) the price of broadband services in Indonesia is still high.

\section{Broadband Internet Regulation for Digital Economy in Indonesia}

To realize the strategies and encourage the achievement of the broadband internet development targets, Indonesia has compiled various regulations including:

\section{Regional Retribution Policy}

Since the establishment of regional autonomy in Indonesia, each region in the territory of Indonesia has its own rules regarding regional retribution for the construction of broadband internet infrastructure.

2. Tariff and Interconnection Regulations

Telecommunication Law No. 36/1999 and the following regulations mandates companies to open wide opportunities for interconnection. Minister Regulation No. 8/2006 regulates interconnection procedures. The crucial issue about interconnection is business-to-business process in determining the service price based on basis issued by the government. This price can affect the price of services paid by consumers.

\section{E-Commerce Regulation}

Indonesia has launched the E-Commerce Roadmap 2017-2019. Draft of Government Regulation about E-Commerce already exists. In addition to government regulation, electronic transactions will also be regulated by the Ministry of Trade regulations. One of the points is marketplaces obligate to register their business to the ministry of trade. In addition, this regulation also requires marketplace user reporting along with traded goods.

4. Security Customer Protection

Law No. 8/1999 concerning consumer protection does not include rights in e-commerce transactions. Consumer protection in online transactions is currently covered by Law No. 19/2016 concerning Information and Electronic Transactions, Government Regulation No. 82/2012 concerning the Implementation of Systems and Electronic Transactions, Ministry of Communication and Informatics (MCI) Regulation No. 20/2016 concerning Protection of Personal Data in Electronic Systems, and MCI Regulation No. 19/2014 concerning Handling of Websites with Negative Contents. Indonesia also established the Indonesia Security Incident Response Team on the Internet and Infrastructure (ID-SIRTII) to minimize the negative impact caused by the internet network (Wahab, 2016).

\section{Regulation of Domestic Component Levels}

At present, there are several domestic component level regulations for telecommunication operations in Indonesia consisting of two; the MCI Regulation No. 41/2009 concerning Procedures for Assessing Achievement of Domestic Component Levels in Telecommunication Sector and MCI Regulation No. 14/2010 concerning Procedures for Assessing Achievement of Domestic Component Levels of Operational Expenditure/Opex in Telecommunication. These regulations will be simplified into the MCI Regulation concerning Procedures for Assessing the Achievement of Domestic Component Levels in Telecommunication. The proposed ministerial regulation includes telecommunication implementation obligations to 
meet the domestic component level of capital and operational expenditure, self-assessment and verification, reporting, supervision and control, and sanctions (Hutabarat, 2018).

6. Spectrum Refarming

The development of broadband internet connectivity is very dependent on the availability of the frequency spectrum. The availability of adequate frequency spectrum allocation will greatly support the sustainability of digital economic growth by ensuring the implementation of financial inclusion, economic contribution, digital citizenship, and social equality (GSMA, 2018).

MCI of Indonesia as a leader in ICT sector has completed refarming the frequency of $800 \mathrm{MHz}$, $900 \mathrm{MHz}, 1800 \mathrm{MHz}$, and 2,1 GHz. Through this process, the use of frequency spectrum becomes more efficient thus the expansion of broadband internet services and penetration can be accelerated. In this condition, an increase in economic growth can be achieved (Khairuddin, 2019).

Refarming is carried out based on several regulation, for instances, MCI Decree No. 1998/2017 concerning Rearrangement of $2.1 \mathrm{GHz}$ Radio Frequency Bands for the Need of Organizing Cellular Mobile Networks and Director General of Postal and Information Technology Resources and Equipment Decree No. 376/2017 concerning Its Technical Guidelines (MCI Prublic Relations Bureau, 2017).

In addition, there are also a number of regulations in the form of ministerial regulations governing the Rearrangement of Radio Frequency Bands for the Need of Organizing Cellular Mobile Networks

Table 2. Spectrum Refarming Regulations (JDIH

\begin{tabular}{cc}
\multicolumn{2}{c}{ Kominfo, 2019) } \\
\hline Ministerial Regulation & Band \\
No. 19/2015 & $1800 \mathrm{MHz}$ \\
No. 30/2014 & $800 \mathrm{MHz}$ \\
$\begin{array}{c}\text { No. 31/2012 (Second } \\
\text { Change of No. 1/2006) }\end{array}$ & $2,1 \mathrm{GHz}$ \\
\end{tabular}

Based on the results obtained, a comparison of aspects of broadband internet development can be formulated in supporting the digital economy in China and Indonesia as follows:

Table 3. Comparison of Results

\begin{tabular}{|c|c|c|}
\hline Aspect & China & Indonesia \\
\hline \multicolumn{3}{|c|}{ Broadband Internet Infrastructure } \\
\hline Internet user (\% of population) & $2017: 54.3$ & $2017: 32.29$ \\
\hline $\begin{array}{l}\text { Fixed broadband subscriber } \\
\text { (per } 100 \text { people) }\end{array}$ & 2017: 26.86 & 2017: 2.29 \\
\hline $\begin{array}{l}\text { Mobile cellular subscriber } \\
\text { (per } 100 \text { people) }\end{array}$ & 2017: 104.58 & 2017: 173.84 \\
\hline $\begin{array}{l}\text { Average connection speed } \\
(\mathrm{Mbps})\end{array}$ & Q1-2017: 7.6 & Q1-2017: 7.2 \\
\hline $\begin{array}{l}\text { International internet BW per } \\
\text { user (kilo bit per second) }\end{array}$ & 2014: 5 & 2016: 6.23 \\
\hline Fiber optic cable length (km) & 2017: 36.06 million & 2019: more than 154 thousand \\
\hline Number of BTS & 2017: 6.041 million & 2016: 163 thousand \\
\hline \multicolumn{3}{|l|}{ Digital Economy Overview } \\
\hline Digital economy growth & 2017: $33.3 \%$ of GDP & 2017: $4 \%$ \\
\hline $\begin{array}{l}\text { Digital economy growth } \\
\text { prediction (US\$) }\end{array}$ & 2035: 16 trillion & 2025: 197 billion \\
\hline Digital economy activity & $\begin{array}{l}\text { - Retail } \\
\text { - Sharing economy } \\
\text { - Online ordering application } \\
\end{array}$ & $\begin{array}{l}\text { - Retail } \\
\text { - Start up } \\
\text { - Online transportation application }\end{array}$ \\
\hline
\end{tabular}




\begin{tabular}{|c|c|c|}
\hline Aspect & China & Indonesia \\
\hline & $\begin{array}{l}\text { - Online payment } \\
\text { - Internet financial product } \\
\text { - Online government (payment } \\
\text { service) }\end{array}$ & - Online payment \\
\hline \multicolumn{3}{|c|}{ Broadband Internet Development Strategy } \\
\hline Basic Policy for Development & $\begin{array}{l}\text { - The } 13^{\text {th }} \text { Five Year Plan China } \\
\text { - Implementation Plan Concerning } \\
\text { the Advancement of Internet Poor } \\
\text { Support (2018-2020) }\end{array}$ & $\begin{array}{l}\text { Indonesia Broadband Plan 2014- } \\
2019\end{array}$ \\
\hline Government contribution & $\begin{array}{l}\text { Subsidies amount to } 30 \% \text { of the total } \\
\text { project }\end{array}$ & $\begin{array}{l}\text { Subsidies amount to } 10 \% \text { of the } \\
\text { total funding need }\end{array}$ \\
\hline Rural Target & $\begin{array}{l}\text { 2020: fixed broadband coverage } 98 \% \\
\text { administrative villages, speed } \\
\text { household } 12 \mathrm{Mbps}\end{array}$ & $\begin{array}{l}\text { 2019: fixed broadband coverage } \\
49 \% \text { households speed } 10 \mathrm{Mbps} \text {, } \\
6 \% \text { population speed } 1 \mathrm{Mbps} \text {. } \\
\text { Mobile access at } 52 \% \text { speed } 1 \\
\text { Mbps. }\end{array}$ \\
\hline Urban Target & $\begin{array}{l}\text { 2020: } 70 \% \text { household speed } 50 \mathrm{Mbps} \text {, } \\
\text { up to } 1 \mathrm{Gbps}\end{array}$ & $\begin{array}{l}\text { 2019: fixed broadband coverage } \\
71 \% \text { household speed } 20 \mathrm{Mbps} \\
30 \% \text { population speed } 1 \mathrm{Mbps} \text {. } \\
\text { Mobile access } 100 \% \text { speed } 1 \mathrm{Mbps} \text {. }\end{array}$ \\
\hline Field Focus Development & $\begin{array}{l}\text { - Education (poor school and special } \\
\text { education) } \\
\text { - Health } \\
\text { - Economy } \\
\text { - Agriculture (Rural) }\end{array}$ & $\begin{array}{l}\text { - Government } \\
\text { - Health } \\
\text { - Education } \\
\text { - Logistic } \\
\text { - Procurement }\end{array}$ \\
\hline Development Strategy & $\begin{array}{l}\text { - Infrastructure deployment subsidies } \\
\text { - Providing high-speed networks at } \\
\text { low cost } \\
\text { - Speed up the realization of } \\
\text { intelligent terminals and application } \\
\text { service } \\
\text { - Improving platform promotion } \\
\text { - Inviting private sector contributions } \\
\text { - Creating a pilot project } \\
\text { - Research for deploying } 5 \mathrm{G} \\
\text { commercial networks } \\
\text { - Increasing bandwidth capacity of } \\
\text { international gateways } \\
\text { - Expanding the reach of BTS for } \\
\text { mobile internet }\end{array}$ & $\begin{array}{l}\text { - Making part of USO } \\
\text { - Infrastructure deployment } \\
\text { subsidies } \\
\text { - Creating a pilot project, an } \\
\text { example of a Wireless } \\
\text { Connectivity Pilot Project for } \\
\text { Rural Broadband } \\
\text { - PPP cooperation scheme } \\
\text { - Encouraging the Universal } \\
\text { Service Obligation Fund Reform } \\
\text { - Capacity building digital through } \\
\text { literacy, computer administration, } \\
\text { and broadband education and } \\
\text { training. } \\
\text { - National Industry } \\
\text { - Stimulating application and } \\
\text { service development } \\
\text { - Encouraging low-cost services } \\
\text { - Increasing consumption } \\
\text { protection } \\
\text { - Low-cost price }\end{array}$ \\
\hline Challenge & $\begin{array}{l}\text { Coordination of regional broadband } \\
\text { networks }\end{array}$ & Literacy of internet users \\
\hline \multicolumn{3}{|l|}{ Regulation } \\
\hline Regulation Focus & $\begin{array}{l}\text { - Cybersecurity } \\
\text { - E-Commerce } \\
\text { - Fintech }\end{array}$ & $\begin{array}{l}\text { - Regional retribution } \\
\text { - Tariff and interconnection } \\
\text { - E-Commerce (on process) } \\
\text { - Security } \\
\text { - Customer protection } \\
\text { - Domestic component level } \\
\text { - Spectrum refarming }\end{array}$ \\
\hline
\end{tabular}




\begin{tabular}{lll}
\hline \multicolumn{1}{c}{ Aspect } & \multicolumn{1}{c}{ China } & \multicolumn{1}{c}{ Indonesia } \\
\hline Regulated in E-Commerce & $\bullet$ Taxation & $\bullet$ Marketplace registration \\
Regulation & $\bullet$ Business registration & $\bullet$ Marketplace reporting along with \\
& $\bullet$ Personal data protection & traded goods \\
& $\bullet$ Intellectual property protection & \\
\hline
\end{tabular}

Comparison of infrastructure aspects shows that the gap of between the percentage of internet users in China and Indonesia is not large, but if it is calculated based on the number of people, the amount will be much different because China's population reaches more than 1.3 billion while Indonesia only reaches more than 260 million. The most significant difference between the countries is indicated by the number of fixed broadband subscribers, 13:1 in comparison. The very unequal comparison of fiber optic cable and the number of BTS shows that deploying broadband internet infrastructure in China as a developed country is very massive. The total length of Indonesia's fiber optic in 2019 is even smaller compared to China's fiber optic in 2017.

Comparison of the digital economy overview aspect shows a quite large gap from the aspect of contribution to GDP. China's digital economy has contributed two digits in GDP growth in its country, while Indonesia only recorded one digit. However, entering 2018, Indonesia's digital economy was predicted to contribute around $10 \%$ to national GDP. China's GDP in 2017 was recorded at US\$ 12.24 trillion while Indonesia's GDP was at US\$ 1.016 trillion. Table 3 also shows that economic activity in China is more varied and unique from the aspect of the sector covered, especially sharing economy in the form of sharing bicycle while in Indonesia, transportation services can only be ordered via online transportation application. From the financial activity sector, the maturity of financial regulations (including fintech) in China has led to the emergence of economic activity in this sector. On the other hand, fintech in Indonesia has not been massively used because of the constraints of its immature regulations.

Comparison of broadband internet development strategy aspects shows that the basic policy of developing broadband internet in China is more based on hierarchy. The derivative policy is made to provide detailed guideline targets for the plans. On one hand, the more detailed the guidelines, the easier it is to execute into programs or action plans form. However, on another hand, overly detailed guidelines will make it difficult for the innovation process thus program execution becomes inflexible. Table 3 also shows that the target coverage and speed of broadband internet in China, both rural and urban, is higher than the target in Indonesia. It is because of the basic telecommunication infrastructures in China, such as the number of BTS and fiber optic, are more improved compared to Indonesia. This condition is predicted to make it easier for China to achieve its broadband internet development target. By comparing the field focus of broadband internet development in these two countries, it is known that China and Indonesia are very concerned about education, health, and economic development. For the government sector, China has started the implementation of broadband internet use, such as the availability of online payment facilities for government services. While Indonesia is currently still in the process of implementing the massive digital economy model. Government services that 
can be paid online are payment of motor vehicle, electricity, and water taxes. Interesting findings are shown by the comparison of broadband internet development strategies. It is found out that both countries appear to have almost same strategies. The results inform that both countries are still implementing subsidies for infrastructure deployment. In Indonesia, this subsidy is intended as a stimulus to encourage the maturity of the project location and attract the involvement of the private sector. In addition, the two countries also encourage the availability of low-cost services thus the services can be reached by the people's purchasing power. Unfortunately, pricing is still running by business-tobusiness model. It is still difficult to be intervened by government. Application development acceleration and pilot projects creation are also established as strategies in both countries. The difference is striking that China has focused on infrastructure development while Indonesia still focuses on capacity building. The Human Development Index by the United Nation places China at position 86 with a value of 0.752 , while Indonesia is at position 116 with a value of 0.694. The Chinese Human Capital Index is recorded at 0.67 while Indonesia is still at 0.53. Comparison of item "challenge" reinforces this finding. The challenge facing China is the coordination of broadband networks at the regional level while Indonesia still has to work hard to increase the literacy of internet users thus, the development of broadband internet can be as expected.

Comparison of regulatory aspects shows that regulations in China are very specific to support broadband internet use for the digital economy. Ecommerce and fintech regulations have been prepared. Indonesia is still formulating regulations on e-commerce, and it does not yet any regulations in place oncerning fintech. This condition is caused by the fact that the banking authorities are still hesitant to implement massive online payments in for everyday basis. Related to e-commerce regulation, Table 3 shows that the main regulations have regulated things that are considered crucial in ecommerce activities. While the principle of this regulations in Indonesia is still separated from that of e-commerce regulation, leaving them less focused. The table also shows that until today, Indonesia remains focusing on regulations for infrastructures such as regional retribution and spectrum refarming.

\section{CONCLUSIONS}

Based on the results and discussion, it can be concluded that the telecommunication infrastructure supporting broadband internet and digital economy regulation in China are more mature than Indonesia's. There is a huge gap between China's digital economy and Indonesia's. Even so, currently Indonesia is being very active in developing its ecommerce. This effort may contribute to Indonesia's promotion to enter the top five economy of 2050 . To realize it, the broadband internet development must be accelerated to support digital economy activities. In addition, Indonesia also needs to try engaging in other digital economic activities for instance, fintech. In addition, the government must also provide its human resources with the knowledges and skills needed in digital economy, including artificial intelligence, data analysis, and blockchain, because human resource is also an important component in the digital economy, in addition to infrastructure development. 
Indonesia also needs to learn from China regarding e-commerce regulations, which must include crucial matters such as taxation and product standards applied to offline trading. This stusy also recommends that collaboration be improved between all parties, including the government, academics, industry, and communities in the success of broadband internet to support digital economy, in China and Indonesia.

\section{ACKNOWLEDGEMENT}

I especially express my gratitude to Yuning Gao, Ph.D from School of Public Policy and Management-Tsinghua University, for the lectures, inspiration, and thoughtful guidances as bases of this research.

\section{REFERENCES}

A4AI. (2018). Broadband Strategies are Essential for Digital Development.

Arner, D. W., \& Barberis, J. (2015). FinTech in China: From the Shadows? The Journal of Financial Perspectives: FinTech, 3(3), 78-91. https://doi.org/10.2139/ssrn.2646618

Biro Humas Kemkominfo. (2017). Dimulainya Penataan Ulang Pita Frekuensi Radio $2.1 \mathrm{GHz}$ untuk Keperluan Penyelenggaraan Jaringan Bergerak Seluler. Retrieved from https://www.kominfo.go.id/content/detail/115 76/siaran-pers-no-232hmkominfo112017tentang-pelaksanaan-refarming-spektrumfrekuensi-21-ghz/0/siaran_pers

CBNEditor. (2018). Over 90\% of China's Poorer Villages to Enjoy Broadband Internet Access by 2019. Retrieved from http://www.chinabankingnews.com/2018/06/0 8/90-chinas-poorer-villages-enjoy-broadbandinternet-access-2019/

chinadaily.com.cn. (2018). Broadband to Cover $90 \%$ of Poor Villages in 2018. Retrieved from http://www.chinadaily.com.cn/a/201806/07/W S5b18e9f4a31001b82571eb70.html

Clinten, B. (2018). Internet Kencang 30 Mbps Palapa Ring Siap Diuji di Indonesia Tengah. Retrieved from

https://tekno.kompas.com/read/2018/12/23/10

225087/internet-kencang-30-mbps-palapa-

ring-siap-diuji-di-indonesia-tengah

CNNIC. (2018). 2015 Statistical Report on Internet Development in China, (January). Retrieved from

https://www.cnnic.cn/hlwfzyj/hlwxzbg/20150 2/P020150203551802054676.pdf

Curran, J., Fenton, N., \& Freedman, D. (2016). Misunderstanding The Internet. Pedagoges: An International Journal, 11(2), 270-277.

Fujino, L. E. (2018). China's New e-Commerce Law: Businesses Should Ready for Stronger Compliance Norms. Retrieved from https://www.china-briefing.com/news/chinanew-e-commerce-law-businesses-ready-newcompliance-norms-2019/

Gharawi, M. A., Pardo, T. A., \& Guerrero, S. (2009). Issues and strategies for conducting crossnational e-Government comparative research. ACM International Conference Proceeding Series, $163-170$ https://doi.org/10.1145/1693042.1693076

Gnezdova, Y. V., Chernyavskaya, Y. A., \& Rubtsova, L. N. (2016). Modern Aspects of the Development of Internet- Economy in Russia. Journal of Internet Banking and Commerce, 21(S4), 1-10.

GSMA. (2018). Mempercepat Tercapainya Perekonomian Digital Indonesia: Mengalokasikan Pita Frekuensi $700 \mathrm{MHz}$ untuk Mobile Broadband.

Gunaratne, R. L., P, V. I., Fernando, S., \& Rohman, I. K. (2015). National Broadband Networks of Malaysia, India, Indonesia, and Australia. Competition and Regulation in Network Industries, 16(1), 23-46.

Hirawan, F. B. (2018). Prospects and Challenges of Digital Technology in Indonesia: A socioeconomic perspective.

Hutabarat, D. (2018). Kominfo akan Sederhanakan Aturan TKDN. Retrieved from https://www.kominfo.go.id/content/detail/152 78/kominfo-akan-sederhanakan-aturantkdn/0/sorotan_media

IndoTelko. (2019). Telkom Komersialkan Kabel Laut Indonesia Global Gateway. Retrieved from https://www.indotelko.com/read/1553137313/t elkom-indonesia-global-gateway

JDIH Kominfo. (2019). Produk Hukum. Retrieved from 
https://jdih.kominfo.go.id/produk_hukum/penc arian?kategori $=$ all $\&$ nomor $=\&$ tahun $=$ all $\&$ cari $=$ penataan\&status_publish=

Jorgenson, D. W., \& Vu, K. M. (2016). The ICT revolution, world economic growth, and policy issues \$. Telecommunications Policy, 1-15. https://doi.org/10.1016/j.telpol.2016.01.002

Katadata.co.id. (2019). Berapa Panjang Jaringan Internet Palapa Ring. Retrieved from https://databoks.katadata.co.id/datapublish/201 9/01/17/berapa-panjang-jaringan-internetpalapa-ring

Kemenkominfo. (2016a). Komunikasi Dan Informatikan Indonesia Buku Putih 2016.

Kemenkominfo. (2016b). Studi Ekonomi Digital di Indonesia sebagai Pendorong Utama Pembentukan Industri Digital Masa Depan.

Kementerian Komunikasi dan Informatika. (2012). Komunikasi dan Informatika Indonesia: Buku Putih 2012. Jakarta: Badan Litbang SDM.

Kementerian PPN/BAPPENAS. (2014). Rencana Pitalebar Indonesia (Indonesia Broadband Plan) 2014-2019: Konektivitas - Inovasi Transformasi. Retrieved from https://ppidkemkominfo.files.wordpress.com/2 014/12/rencana_pitalebar_indonesia_20142019.pdf

Khairuddin, I. (2019). Refarming Selesai, Frekuensi $800 \mathrm{MHz}$ dan $900 \mathrm{MHz}$ Jadi Lebih Efisien. Retrieved from https://selular.id/2019/04/refarming-selesaifrekuensi-800-mhz-dan-900-mhz-jadi-lebihefisien/

Kompas.com. (2018). Kontribusi Pasar Digital Terhadap PDB Diprediksi 10 Persen Tahun Ini. Retrieved from https://ekonomi.kompas.com/read/2018/02/15/ 070000326/kontribusi-pasar-digital-terhadappdb-diprediksi-10-persen-tahun-ini

Mastel. (2016). Standar Layanan Internet Indonesia. Retrieved from http://www.mastel.id/standarlayanan- internet-di-indonesia/

Mitrovic, D. (2015). Broadband adoption, Digital Divide, and The Global economic Competitiveness. Economic Annals, LX(207), 95-115. https://doi.org/10.2298/EKA1507095M

Molasiarani, K. (2017). Ekonomi Digital Diprediksi Penopang Ekonomi 2018.

Pradhan, R. P., Arvin, M. B., \& Norman, N. R. (2015). Technology in Society The dynamics of information and communications technologies infrastructure, economic growth, and fi nancial development: Evidence from Asian countries. Technology in Society, 42, 135-149. https://doi.org/10.1016/j.techsoc.2015.04.002

Salahuddin, M., \& Gow, J. (2015). The effects of Internet usage, financial development and trade openness on economic growth in South Africa: A time series analysis and. TELEMATICS AND INFORMATICS. https://doi.org/10.1016/j.tele.2015.11.006

Shenggao, Y. (2018). WIC Adds Vitality to China's Digital Economy. Retrieved from http://www.chinadaily.com.cn/a/201811/07/W S5be2757ea310eff303287248.html

Sumartomdjon, M. (2018). Nilai Transaksi Go-Jek Nyaris Rp 10 Triliun per Tahun. Retrieved from https://industri.kontan.co.id/news/nilaitransaksi-go-jek-nyaris-rp-10-triliun-per-tahun

Tari, D. N. (2019). Tahun Ini, XL Akan Perpanjang Fiber Optik $2.500 \mathrm{Km}$ Lagi. Retrieved from https://teknologi.bisnis.com/read/20190405/10 1/908194/tahun-ini-xl-akan-perpanjang-fiberoptik-2.500-km-lagi

Wahab, R. A. (2016). Analisis Perkembangan Internet Broadband di Wilayah Perbatasan Provinsi Sulawesi Utara. Jurnal Penelitian Pos Dan Informatika, 6(2), 201-226. https://doi.org/10.17933/jppi.2016.060206

Wanda, P. (2018a). Menyambut "Digital Disruption" Indonesia 2018. Retrieved from https://www.kompasiana.com/wpwawan/5a4d d363ab12ae13f238ad42/menyambut-digitaldisruption-indonesia-2018?page $=$ all

Wanda, P. (2018b). Menyambut Gelombang Baru "Digital Economy" di Tanah Air. Retrieved from

http://ppidunia.org/2018/11/26/menyambutgelombang-baru-digital-economy-di-tanah-air/

Xinhua. (2018). China Focus: China Adopts ECommerce Law to Improve Market Regulation. Retrieved from http://www.xinhuanet.com/english/201808/31/c_137434452.htm

Zhang, L. (2018). China: E-Commerce Law Passed. Retrieved from http://www.loc.gov/law/foreignnews/article/china-e-commerce-law-passed/

Zhou, W., Arner, D. W., \& Buckley, R. P. (2015). Regulation of Digital Financial Services in China: Last Mover or First Mover? Tsinghua China Law Review, 8(1), 1-39. 
